\title{
Aplikasi Android untuk Monitoring Lahan Pertanian secara Realtime Berbasis Internet of Things
}

\author{
http://dx.doi.org/10.28932/jutisi.v6i3.3039
}

\author{
Jihot Lumban Gaol ${ }^{\# 1}$, Hindriyanto Purnomo ${ }^{* 2}$, Budhi Kristianto ${ }^{\# 3}$ Radius Tanone ${ }^{凶 * 4}$, Yos Richard Beeh ${ }^{\# 5}$ Nina \\ Setiyawati ${ }^{* 6}$, Markus Permadi ${ }^{\# 7}$ Raynaldo $^{* 8}$, Riko Yudistira ${ }^{\# 9}$ \\ Jurusan Teknik Informatika, Universitas Kristen Satya Wacana \\ Jl. Dr. O Notohamidjojo, Kel.Blotongan, Kec. Sidorejo, Salatiga \\ ${ }^{1}$ jihot.gaol1@gmail.com, ${ }^{2}$ hindriyanto.purnomo@uksw. edu, ${ }^{3}$ budhik@uksw.edu, \\ ${ }^{4}$ radius.tanoneduksw. edu, ${ }^{5}$ yos. beeh@uksw.edu, ${ }^{6}$ nina.setiyawatiduksw. edu, \\ ${ }^{7} 672015189$ @student.uksw.edu, ${ }^{8}$ rayzerdodo@gmail.com, ${ }^{9}$ yudist9612@gmail.com
}

\begin{abstract}
The development of technology is very helpful in agriculture by using the internet to get the information we need. The problem that farmers think of is that they cannot easily and quickly get information in the form of light intensity, precipitation, soil $\mathrm{pH}$, soil moisture, soil temperature, humidity and air temperature. When farmers get the information they need from agricultural land, they usually get information through the internet so they are considered less efficient as it is quite time consuming. To solve this problem, a system is designed using the research and development method (RnD). A new Android-based application that can display data in text and graphics that are more easily accessible to farmers. This study creates an Androidbased mobile application based on tests using the Android interface to display information about agricultural land conditions and display graphical data that is updated every 5 minutes.
\end{abstract}

Keywords- Land monitoring; Agriculture; IoT; Android Application

\section{Pendahuluan}

Perkembangan teknologi berkembang dengan pesat dari waktu ke waktu. Beberapa contoh perkembangan teknoligi mulai dari mobil pintar dimana mobil bisa berjalan sendiri ke berbagai tujuan tanpa harus dikemudikan oleh manusia, hingga perangkat rumah pintar semacam Alexa yang berfungsi untuk mengingatkan manusia melakukan aktifitas sesuai jadwal. Teknologi terbaru ini merupakan sebagian kecil dari Internet of Things. Internet of Things (IoT) merupakan sebuah konsep dari suatu objek yang dapat mentransfer data melalui jaringan tanpa adanya interaksi antar manusia atau manusia ke komputer. Internet of Things (IoT) merupakan struktur objek, orang disediakan dengan kemampuan untuk memindahkan data melalui jaringan tanpa memerlukan interaksi dari manusia ke manusia yang merupakan sumber ke tujuan atau interaksi manusia ke komputer[1].
Demikian juga teknologi mobile yang dewasa ini berkembang pesat. Berbicara mengenai perkembangan teknologi mobile, adapun secara spesifik dari teknologi ini sendiri yang berkembang di masyarakat. Spesifik yang dimaksud adalah jenis sistem operasi dari teknologi mobile itu sendiri. Seperti yang diketahui bahwa saat ini beredar sistem operasi seperti android, iOS, chrome dan lain sebagainya. Menurut survey https://gs.statcounter.com [2], perkembangan teknologi mobile dengan sistem operasi Android adalah yang paling besar yaitu di atas $80 \%$ pada periode pengukuran Agustus 2018-Agustus 2019. Urutan kedua diikuti oleh iPhone yang berada di bawah $20 \%$ dari total pengguna di Indonesia. Melihat tren ini maka penerapan teknologi mobile Android menjadi pilihan tepat dalam menjadi salah satu solusi menyelesaikan persoalan di tengah masyarakat.

UMKM sayuran organik di Dusun Sidomukti Desa Kopeng merupakan UMKM sayuran yang bergerak dibidang organik. Shofyan Adi Cahyono, adalah pemilik UMKM Sayur organik merbabu (SOM). Awalnya usaha ini dijalankan oleh orang tuanya pada tahun 2007 dan hanya mempekerjakan anggota keluarga. Karena usaha sayuran organik ini memiliki peluang dengan prospek jangka panjang maka pemilik usaha mulai mengajak beberapa petani sayuran organik yang memiliki komitmen dan serius untuk menjalankan usaha sayuran organiknya. Dalam proses perawatan sayuran para petani selalu melakukan usaha maksimal, salah satunya dengan memperhatikan perubahan iklim. Perubahan iklim yang selalu berubah dapat mempengaruhi pertumbuhan sayuran. Untuk mengatasi hal tersebut pemilik lahan dan para petani selalu memeriksa kondisi lahan dengan cara manual sehingga informasi yang didapat tidak efektif karena hanya mengandalkan prediksi seadanya. Pada penelitian ini, dilakukan perancangan aplikasi yang dapat membantu pemilik lahan dan para petani dalam mendapatkan informasi yang lebih akurat[3].

Rumusan masalah dalam penelitian ini adalah merancang aplikasi mobile berbasis android untuk monitoring lahan 
dimana data monitoring lahan diperoleh dari IoT (sensorsensor) yang telah dirancang sebelumnya. Tujuan dari penelitian ini untuk membantu pemilik lahan dan para petani dalam mendapatkan informasi dan perkembangan lahan secara cepat. Sedangkan manfaat dari penelitian ini adalah pemilik lahan dan para petani bisa mendapatkan informasi dan perkembangan lahan tanpa harus pergi ke lokasi pertanian.

\section{TINJAUAN PUSTAKA}

Penelitian terdahulu diperlukan sebagai pendukung dalam melakukan penelitian. Penelitian terdahulu digunakan sebagai bahan pertimbangan dan sebagai acuan untuk memperkaya teori. Pada penelitian yang berjudul Aplikasi Android untuk Monitoring kualitas Lahan Pertanian membahas bagaimana membangun aplikasi android menggunakan text box dan tombol untuk menampilkan hasil sensor. Sensor yang digunakan pada penelitian ini adalah sensor DS18B20 waterproof, sensor kelembapan tanah dan sensor $\mathrm{pH}$ meter analog kit. Software kualitas lahan pertanian dirancang dengan menggunakan aplikasi android apk. Apliksi dibangun dengan menggunakan android studio ver.3.1.2. aplikasi ini dilengkapi dengan sistem rekap basis data dengan tujuan untuk memanggil basis data pada server internet. Data sensor yang sudah olah akan ditampilkan ke LCD lalu data dikirim ke server internet menggunakan Mikrokontroller. Hasil pembacaan sensor ditampilkan dengan menggunakan LCD dot metric 2x16, warna biru. LCD dapat menampilkan data sebanyak 2 baris atas dan 16 kolom bawah. Aplikasi LCD bertujuan untuk menampilkan data hasil sensor berupa sensor suhu, sensor kelembapan dan sensor Ph meter. Yang menjadi acuan dari penelitian di atas adalah penggunaan text box untuk menampilkan hasil sensor[4].

Pada penelitian dengan judul Rancang Bangun Sistem Monitoring Kelembapan Tanah dan Suhu Udara Berbasis GSM SIM900A dan Arduino Uno membahas bagaimana membangun sistem monitoring. Sensor yang digunakan meliputi sonsor DHT11, soil moisture sensor dan Arduino Uno. Tahap selanjutnya adalah merancang perangkat lunak (software) dan perangkat keras (hardware). Perancangan perangkat lunak dengan pemrograman Arduino menggunakan perangkat lunak Arduino IDE (Integrated Development Environment). Perancangan perangkat keras dimulai dengan membangun blok dahulu. Komponen utama dalam mengendalikan sistem adalah Arduino uno. Sedangkan receiver dari sistem adalah GSM SIM900A. Data yang di input dari Arduino akan diterima oleh GSM SIM900A untuk diproses selanjutnya data akan dikirim berupa SMS pemberitahuan kepada pemilik tanaman. Hasil sensor kelembaban tanah, suhu dan ketinggian air akan mendeteksi keadaan untuk menyesuaikan dengan yang sudah ditentukan sebelumnya. Yang menjadi acuan dari penelitian ini adalah pemanfaatan sensor Arduino Uno dalam mendapatkan data dari lahan[5].

Pada penelitian yang berjudul Sistem Kontrol dan Monitoring Hidropnik berbasis Android membahas bagaimana membangun aplikasi android yang berfungsi memantau kondisi pada hidroponik berupa kondisi ph air, suhu air, ketinggian air, EC air, temperatur dan kelembaban udara. Aplikasi dibangun menggunakan Android Studio yang dengan bahasa pemograman java. Komunikasi antara aplikasi Android dan hidroponik dilakukan melalui internet digunakan protokol MQTT. protokol MQTT adalah protokol yang memungkinkan beberapa device saling mengirim dan menerima data berupa string dengan mudah. Dalam MQTT dibutuhkan broker yang bertujuan untuk menerima pesan apa saja dari suatu topik yang masuk dan akan meneruskan pesan tersebut ke client yang terkoneksi. Yang menjadi acuan dari penelitian ini adalah pemanfaatan sensor Arduino Uno dan perancangan aplikasi menggunakan java[6].

Berdasarkan penelitian terdahulu yang telah dilakukan terkait pembuatan aplikasi android, maka akan dilakukan penelitian yang membahas tentang Pembuatan Aplikasi Mobile Berbasis Android untuk Monitoring Lahan. Dari hasil penelitian yang sudah ada dapat diambil beberapa acuan dalam yaitu perancangan aplikasi dibangun menggunakan java, pemanfaatan sensor Arduino Uno sebagai alat sensor untuk mendapatkan data dari lahan dan penggunaan text box dalam menampilkan data sensor yang selanjutnya di kirimkan ke database melalui web service. Data yang dihasilkan berupa intensitas cahaya, curah hujan, PH tanah, suhu tanah, kelembaban udara, kelembaban tanah dan suhu udara.

IoT merupakan segala tindakan dimana pelakunya saling berinteraksi, dimana dalam proses pelaksanaannya memanfaatkan internet. Ada banyak Internet of Thing (IoT) yang dapat kita temui dalam banyak aktifitas, contohnya adalah : transportasi online, e-learning, e-commerce, , live streaming, pemesanan tiket online dan masih banyak lagi, bahkan sampai alat bantu di bidang tertentu misalnya remote temperature sensor, dan lain sebagainya yang memanfaatkan internet sebagai media dalam proses pelaksanaannya[7].

Android merupakan sistem operasi pada telepon seluler dan berbasis Linux. Pada Android disediakan platform terbuka untuk para pengembang bisa merancang aplikasi mereka sendiri. Android dikembangkan oleh Android Inc, yang merupakan perusahaan baru untuk membuat perangkat lunak pada ponsel, kemudian beralih pada Google Inc setelah dibeli [8].

\section{METODE PENELITIAN}

Dalam penelitian ini digunakan Research and Development $(\mathrm{RnD})$ sebagai proses dalam penelitian menurut Sugiyono [9]. Model yang digunakan dalam penelitian yaitu model prosedural, model yang 
menggariskan pada tahap pengembangan dan bersifat deskriptif. Tahapan penelitian dapat dilihat pada Gambar 1 .

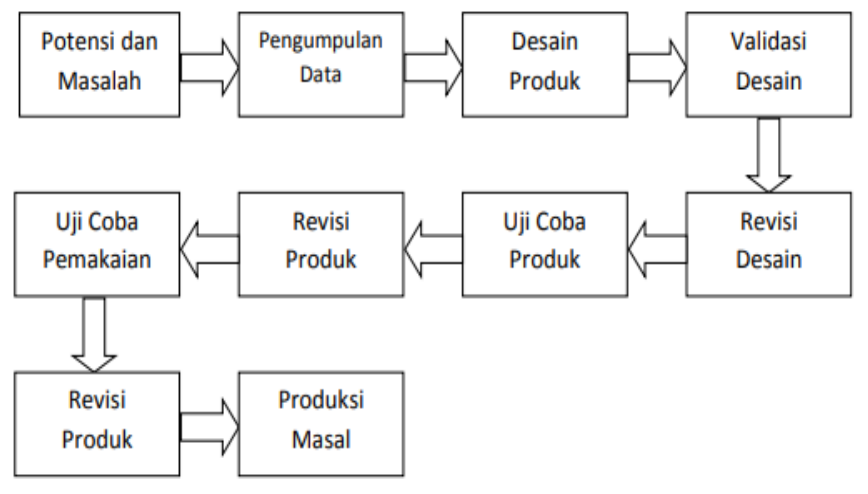

Gambar 1 Tahapan Penelitian berikut:

Tahapan pada Gambar 1 dapat dijelaskan sebagai

\section{Potensi dan Masalah}

Dalam tahapan pertama dimungkinkan adanya potensi dan juga masalah. Dari hasil wawancara bersama bapak Sofyan selaku pemilik lahan pertanian Sayur organik, Kopeng (SOM) di daerah kopeng, membahas tentang kendala untuk mendapatkan informasi perkembangan lahan yang didapat dengan cara manual atau atau harus melalui web. Dari pembahasan Bersama bapak Sofyan selaku pemilik lahan maka dapat diperoleh potensi permasalahan dan juga dapat dijadikan masalah pada penelitian. Tujuan dari penelitian ini adalah memudahkan petani atau pemilik lahan dalam mendapatkan informasi dengan lebih cepat dan efisien.

\section{Pengumpulan Data}

Pada tahap pengumpulan data pencarian teori-teori dilakukan sebagai sumber penting yang diperoleh dari buku, internet, dan wawancara terhadap pihak terkait dalam perancangan aplikasi pada penelitian ini.

\section{Desain Produk}

Pada tahapan ini dilakukan perancangan aplikasi dengan menggunakan perangkat lunak Unified Modeling Language $(U M L)$ yang digunakan untuk memodelkan kebutuhan yang dapat mempermudah dalam proses pembangunan sistem. Pemodelan kebutuhan dapat dibuat seperti use case diagram, class diagram, arsitektur sistem dan activity diagram.

4. Validasi Desain

Tahapan ini merupakan tahap dimana peneliti berkoordinasi dengan supervisior dalam proses perancangan sistem yang akan digunakan kedepannya. Perancangan system dilakukan untuk bisa digunakan secara rasional. Hal ini dilakukan sebagai tahap untuk mereview produk, dan memberikan arahan dan masukan untuk perbaikan.

\section{Revisi Desain}

Tahap ini dilakukan berdasarkan pada hasil uji coba dari validasi awal dengan maksud untuk memperoleh informasi kualitatif tentang program atau produk yang dikembangkan. Selanjutnya, akan dilakukan penyesuaian jika adanya kekurangan pada hasil validasi untuk tujuan pengembangan sistem.

\section{Uji Coba Produk}

Pada tahapan ini dilakukan pengujian awal dengan maksud untuk mencari bug serta kekurangan yang ada secara terbatas. Berdasarkan uji coba yang dilakukan didapatkan beberapa masalah sehingga dibutuhkan revisi untuk pemantapan produk.

\section{Revisi Produk}

Dari hasil uji coba pembuat. Diharapkan hasil produk yang lebih baik, uji coba dilakukan dengan melibatkan Stakeholder yang lebih besar. Dimaksud untuk menentukan keberhasilan dari produk yang dibuat dalam pencapaian tujuan serta pengumpulan informasi.

\section{Uji Coba Produk}

Pengujian dilakukan dengan melibatkan 5 Stakeholder yang kemudian dilakukan wawancara, dan observasi untuk kemudian dilakukan analisis untuk produk yang lebih baik.

\section{Revisi Produk}

Ketika terdapat fitur yang error dalam penggunaan dan terdapat masalah pada proses berjalannya system, maka akan dilakukan perbaikan dan dilakukan revisi berdasarkan saran dari pengguna dalam uji coba untuk mendapatkan produk yang lebih baik.

10. Produk Massal

Tahapan ini merupakan implementasi sistem yang akan digunakan oleh pemilik lahan dan para petani. Sistem ini diharapkan dapat membantu dan mempermudah para petani dalam penggunaan untuk mendapatkan informasi.

Perancangan sistem pada penelitian ini adalah dengan menggunakan metode prototype. Metode ini sangat cocok digunakan karena dapat membangun sebuah perangkat yang dapat terus-menerus dikembangkan untuk hasil produk lebih maksimal[10].

Tahapan yang dilakukan dalam metode prototype :

1. Pengumpulan data awal

Tahap awal dari metode ini adalah dengan menentukan tempat penelitian yaitu pada PO. Sayur Organik Merbabu (SOM). Tahap ini bertujuan untuk mengumpulkan informasi yang didapat dari pengguna berupa hal apa yang dibutuhkan pengguna dalam perancangan apliksi, identifikasi masalah dan ukuran pasti dari produk dibuat berdasarkan keinginan pengguna. 


\section{Quick design (desain cepat)}

Pada tahap ini, aplikasi di desain berdasarkan gambaran umum produk yang sesuai dengan keinginan pengguna. Desain yang di hasilkan nantinya akan dilanjutkan dengan membangun aplikasi.

3. Pembuatan prototype

Pembuatan prototype dilakukan dengan melakukan coding dilakukan untuk menghasilkan aplikasi SISMOLA menggunakan android studio. Aplikasi didesain secara umum untuk selanjutnya dikembangkan kembali.

4. Evaluasi terhadap prototype

Pengguna akan melakukan uji coba dan evaluasi terhadap produk yang sudah ada, setelah selesai pengguna akan memberikan feedback apabila dibutuhkan pengembangan lebih lanjut.

5. Perbaikan prototype

Setelah melakukan evaluasi. Selanjutnya akan dilakukan pembuatan produk dengan tipe yang sebenarnya sesuai dengan hasil dari evaluasi prototype.

6. Produksi akhir

Pada tahap ini produk akan dikembangkan terus menerus sampai produk yang di hasilkan mendekati apa yang diinginkan pengguna. Beberapa acuan dalam produk akhir adalah sebagai berikut :

1. Informasi yang cukup didapatkan terhadap kebutuhan pengguna untuk melakukan pengembangan produk.

2. Apabila ada masalah, maka akan ditemukan solusi dengan membuat produk paling mendekati apa yang diinginkan pengguna dan tetap mempertimbangkan manfaat serta kegunaan dari produk.

3. Jika produk prototype yang dihasilkan sudah mendekati kebutuhan pengguna untuk dijadikan acuan produk yang akan dikembangkan[11].

Akan dilakukan pembuatan use case diagram untuk menggambarkan fungsionalitas terhadap suatu sistem beserta aktor yang terlibat didalamnya. Gambar 2 merupakan use case aplikasi Sistem Monitoring Lahan.

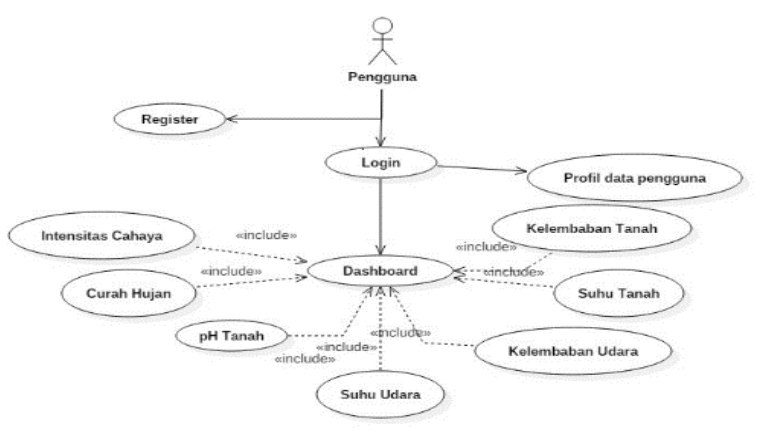

Gambar 2. Use case diagram
Gambar 2 terlihat 1 user dimana user tersebuat memiliki akses untuk melakukan registrasi, setelah registrasi sukses user dapat langsung login lalu masuk ke halaman utama. Pada halaman utama user dapat dengan mudah mendapatkan informasi yang dibutuhkan.

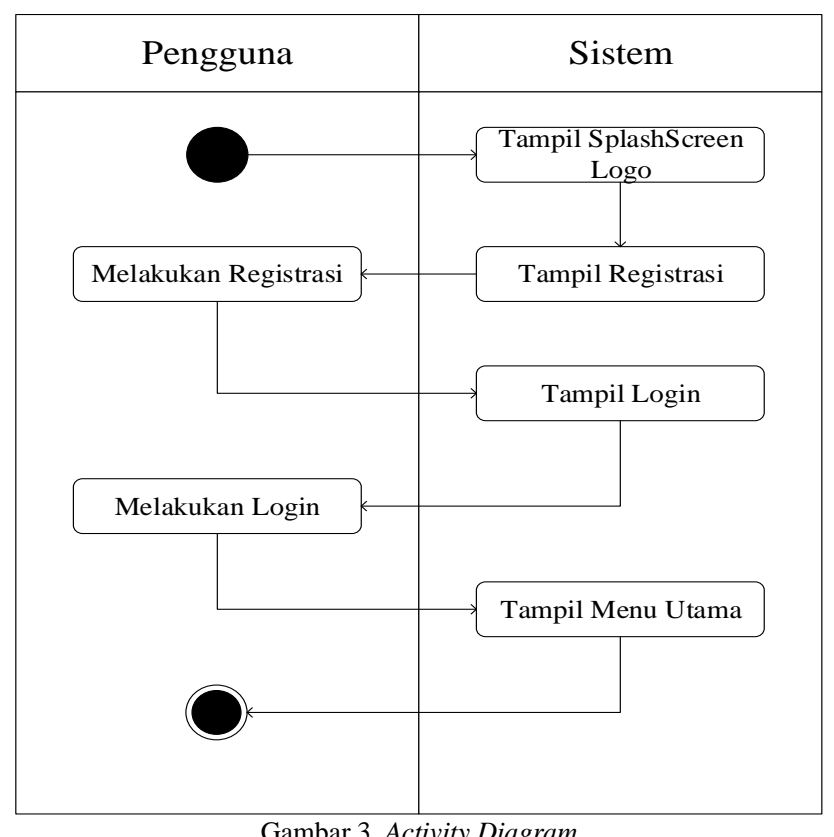

Pada Gambar 3 user melakukan registrasi dan melakukan login jika login sukses maka user akan langsung ditujukan pada tampilan menu utama.

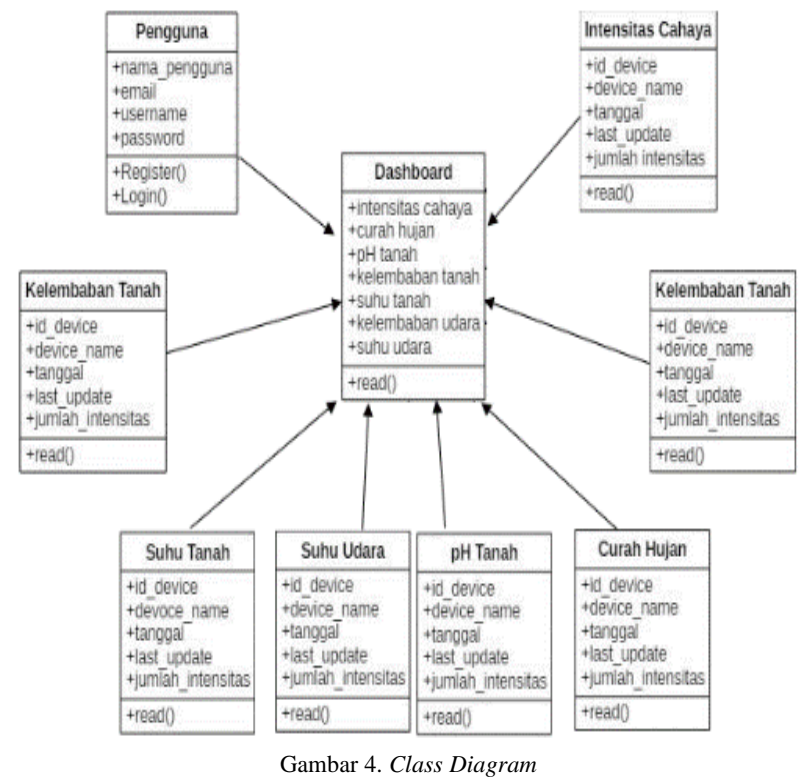

Pada Gambar 4 menjelaskan bahwa pengguna masuk kedalam halaman registrasi, setelah registrasi sukses maka pengguna bisa login lalu masuk ke menu utama, dan smartphone pengguna harus terhubung dengan internet. 
Selanjutnya pengguna bisa ke menu navigation drawer untuk melihat grafik perkembangan data.

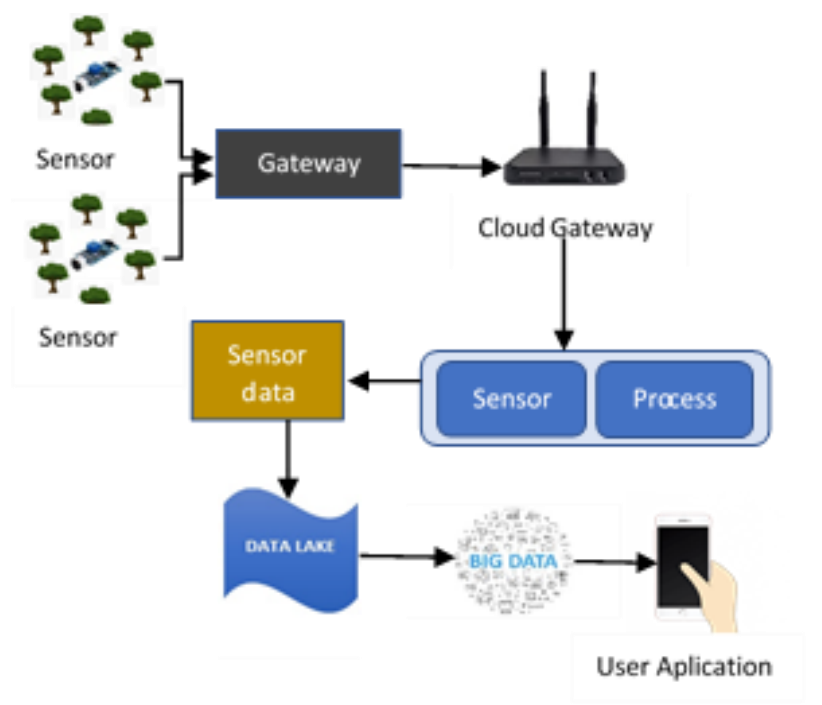

Gambar 5. Arsitektur sistem

Gambar 5 menunjukan arsitektur dari sistem yang digunakan, dimana alat sensor akan ditempatkan pada masing-masing lahan, 7 sensor akan melakukan proses pembacaan data lahan yang nantinya akan dikirimkan ke database melalui jarigan internet. Data yang dihasilkan dari 7 modul sensor berupa intensitas cahaya, curah hujan, PH tanah, suhu tanah, kelembaban udara, kelembaban tanah dan suhu udara Gateway merupakan perantara atau konektifitas antara sensor dan internet. Selain menyediakan konektifitas gateway juga akan melakukan preprosesing atau proses awal sebelum dikirim ke claude, proses awal dilakukan dengan tujuan untuk memfilter data yang paling perlu untuk dikirimkan dan juga mengagregasikan data dalam kurun waktu tertentu dengan tujuan untuk menghemat bandwidth serta mempercepat proses pengiriman ke internet. Claude Gatway berperan sebagai kompresi data, keamanan serta pemindahan data secara cepat dan rendah daya. Claude Gateway bisa berupa wifi, jarigan GSM dan lain-lain. Sensor dan Proses akan memastikan transisi dari input data ke Data Lake berjalan dengan baik. Data Lake berperan sebagi penampung raw data dari berbagai device, untuk selanjutnya diolah dalam Big Data Warehouse. Data yang dihasilkan biasanya disimpan dalam bentuk yang tidak terstruktur. Data yang berasal dari Data Lake akan diubah serta disiapkan dalam bentuk yang lebih terstruktur, serta akan diambil data yang lebih beguna. User Aplication merupakan antar muka pengguna berupa mobile application berbasis android untuk menampilkan data yang dibutuhkan pengguna.

\section{HASIL DAN PEMBAHASAN}

Hasil yang didapat dari pembahasan ini adalah aplikasi mobile berbasis android. Perancangan aplikasi mobile berbasis android, dengan merancang bagian tampilan pada bagian register, login dan menu utama. Perancangan aplikasi dibuat untuk menampilkan data atau informasi yang diperoleh dari request yang dilakukan aplikasi mobile dan diteruskan ke database melalui web service untuk mengambil data dan ditampilkan dalam bentuk json ke web service untuk ditampilkan ke mobile menggunakan java.

Pada lahan pertanian sayur oraganik merbabu (SOM) di kopeng telah disediakan alat sensor dimana fungsi alat sensor tersebut untuk mendapatkan informasi berupa data Intensitas Cahaya, Curah Hujan, PH Tanah, Kelembapan Tanah, Suhu Tanah, Kelembapan Udara,Suhu Udara. Alat sensor ini merupakan sebuah rangkaian dari IoT yang telah dirancang sebelumnya dan ditempatkan pada lahan pertanian. Tampilan sensor dari rangkaian IoT dapat ditunjukkan pada Gambar 6 berikut.

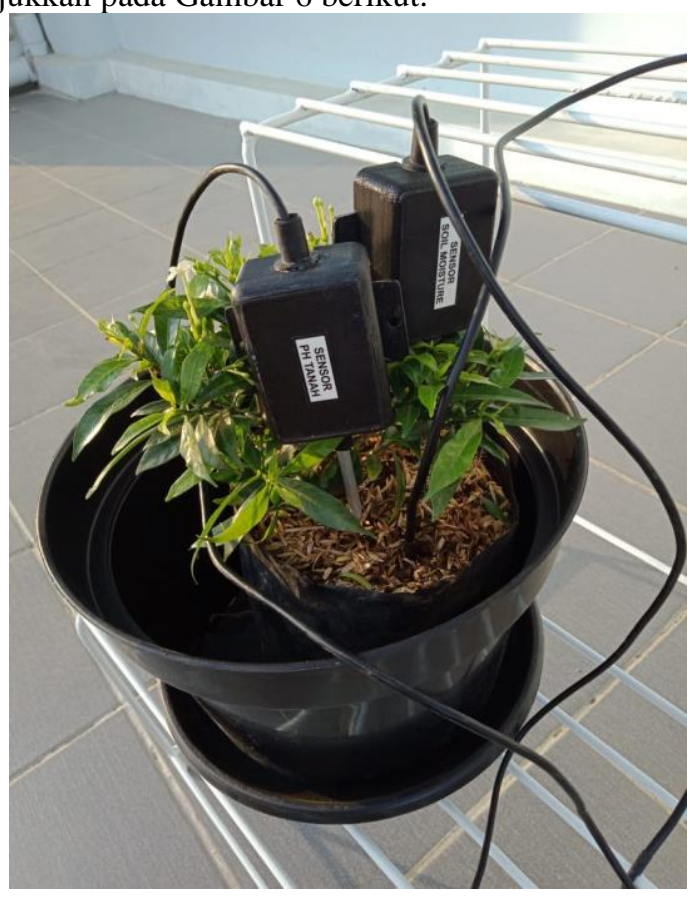

Gambar 6. Tampilan Sensor Ph dan Kelembaban Tanah

Gambar 6 di atas merupakan tampilan sensor $\mathrm{Ph}$ dan Kelembaban tanah yang digunakan pada rangkaian IoT. Untuk sensor lainnya memiliki bentuk yang sama namun fungsi yang berbeda. Data yang diperoleh dari sensor nantinya akan di kirimkan ke database memalui web service. Data yang sudah tersedia dalam database bisa diakses oleh pemilik lahan dan para petani yang ada di daerah kopeng melalui aplikasi SISMOLA yang sudah selesai dibangun. Data yang dihasilkan merupakan data dari hasil sensor terbaru, dan data dalam bentuk grafik dimana data dalam grafik merupakan hasil sensor yang ditampilkan dalam jangka waktu yang cukup lama, sehingga pemilik lahan dan 
para petani bisa melihat perkembangan kondisi lahan dari waktu ke waktu. Aplikasi yang telah selesai dibangun selanjutnya digunakan oleh pemilik lahan dan para petani yang ada pada lahan pertanian sayur oraganik merbabu (SOM) di kopeng.

Pengujian aplikasi mobile berbasis android untuk monitoring lahan dilakukan dengan melakukan pengujian antarmuka aplikasi. Pengujian dilakukan menggunakan smartphone berbasis android yang berfungsi sebagai antarmuka aplikasi. Smartphone terlebih dahulu diinstal aplikasi yang sudah dibangun untuk menampilkan data pada lahan pertanian. Selanjutnya, smartphone harus tersambung ke internet untuk bisa registrasi, login, dan aplikasi bisa menampilkan data dari kondisi lahan untuk waktu terbaru yang meliputi data Intensitas Cahaya, Curah Hujan, PH Tanah, Kelembapan Tanah, Suhu Tanah, Kelembapan Udara,Suhu Udara dan menampilkan data grafik Intensitas Cahaya, grafik Curah Hujan, grafik PH Tanah, grafik Kelembapan Tanah, grafik Suhu Tanah, grafik Kelembapan Udara,dan grafik Suhu Udara.

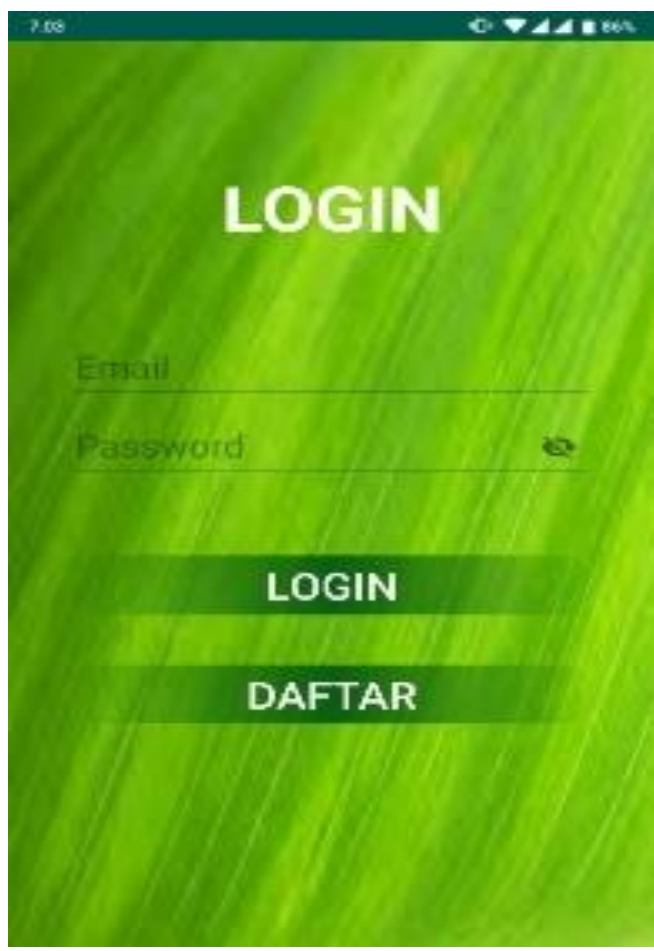

Gambar 7. Tampilan registrasi dan login

Gambar 7 menunjukkan form register dan login, dimana untuk menggunakan aplikasi ini pengguna terlebih dahulu harus melakukan register dengan inputan berupa nama, email, dan password. Data yang ada akan di kirim ke web service dan disimpan ke database. Jika register berhasil maka pengguna dapat login menggunakan email dan password yang terdaftar.

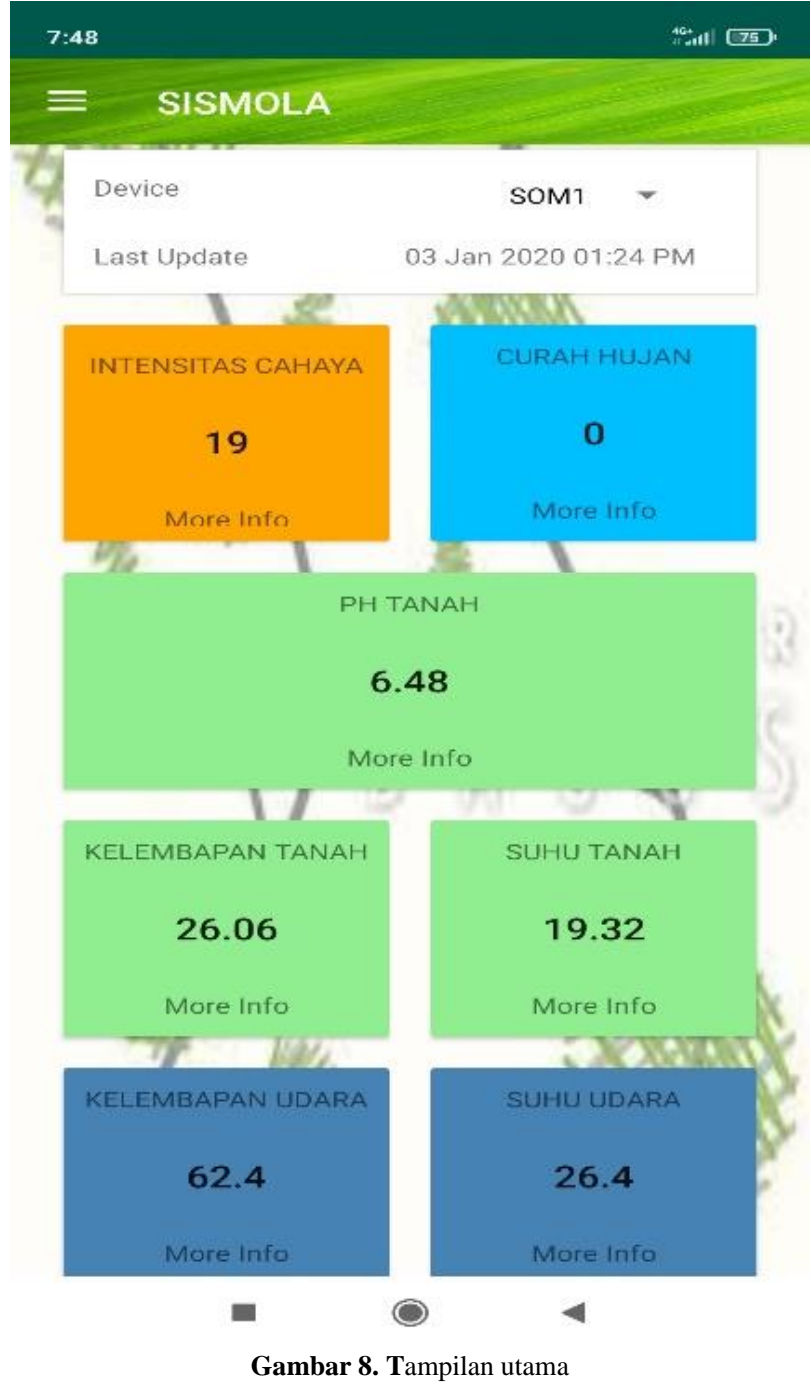

Gambar 8 merupakan tampilan utama pada aplikasi yang di dalamnya terdapat seluruh data terbaru, data yang ditampilkan diambil dari web service dan data tersebut akan selalu berubah seiring berjalannya waktu. Pada tampilan utama terdapat dua device pilihan, yaitu FTIDEV dan SOM. Device ini merupakan alat sensor yang di tempatkan di lokasi lahan secara terpisah. Tujuan dari device ini untuk menunjukan data lahan dari lokasi sensor yang berbeda dengan nama FTIDEV yang ditempatkan daerah A sedangkan Device SOM adalah nama alat yang di tampatkan di daerah B secara terpisah. Setiap device memilik data yang berbeda-beda, hal ini dikarenakan lokasi dari setiap device berada di lokasi yang tidak sama. Data dari setiap device diperbarui setiap satu jam, data yang di tampilkan berupa data dari intensitas cahaya, curah hujan, ph tanah, kelembapan tanah, suhu tanah, kelembapan udara, dan suhu tanah. 


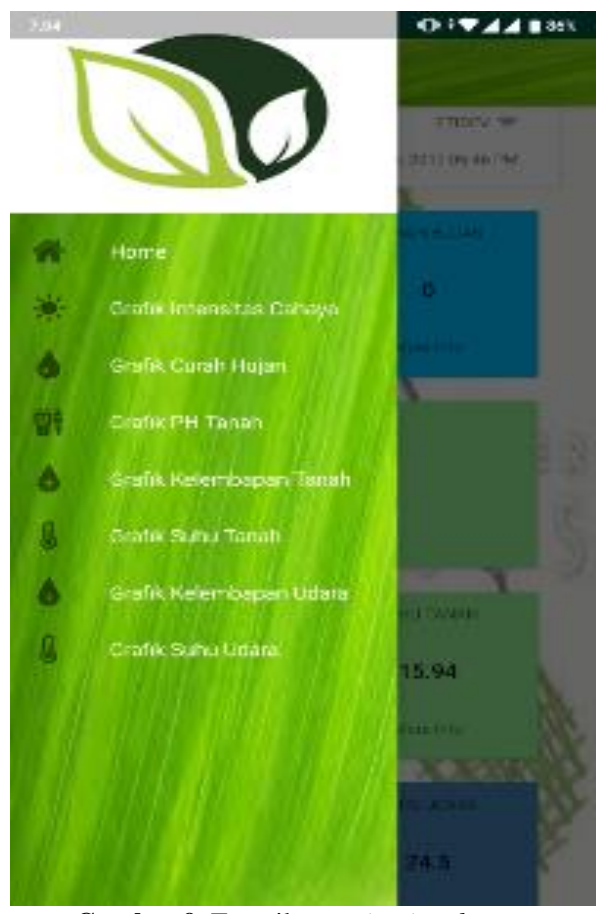

Gambar 9. Tampilan navigation drawer

Gambar 9 merupakan navigation drawer dimana pengguna dapat melihat grafik dari masing-masing bagian. Data grafik yang di tampilkan meliputi grafik Intensitas Cahaya, grafik Curah Hujan, grafik PH Tanah, grafik Kelembapan Tanah, grafik Suhu Tanah, grafik Kelembapan Udara, dan Suhu Tanah.

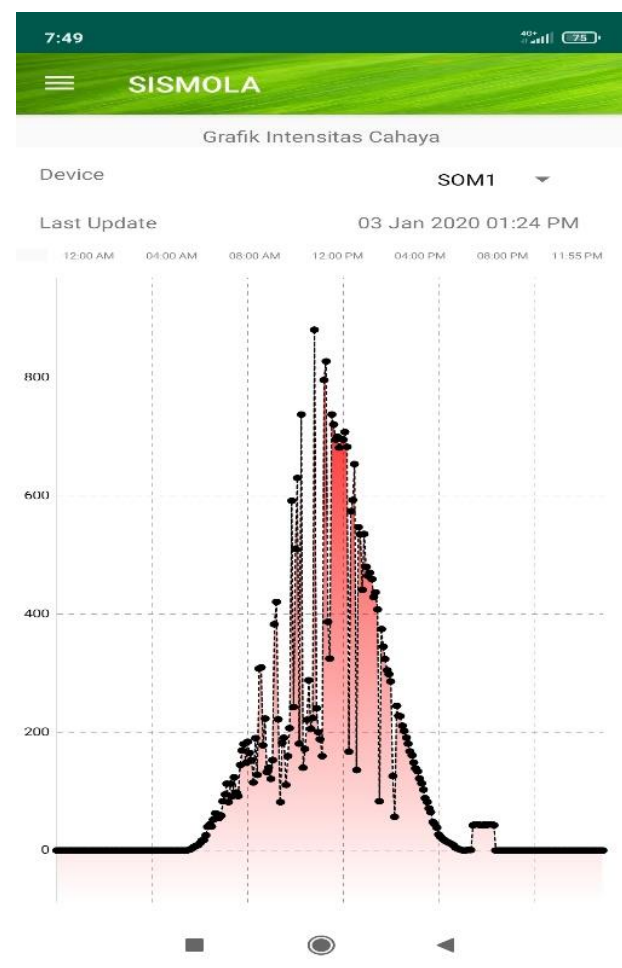

Gambar 10. Grafik Intensitas Cahaya
Gambar 10 merupakan tampilan Grafik Intensitas Cahaya dimana setiap data dari sensor yang ditampilkan berupa grafik. Alat sensor akan menangkap data intensitas cahaya dan segera mengirimkan data hasil sensor ke database melalui web service setiap 5 menit. Data yang dikirimkan selanjutnya akan ditampilkan pada aplikasi sismola dengan memanfaatkan API yang dibuat pada web server. Pada grafik data yang ditampilkan merupakan data yang diambil dari database selama satu hari untuk melihat perkembangan data sepanjang satu hari. Satuan intensitas cahaya adalah candela dimana pada Gambar 9 terdapat nilai candela yang disiapkan pada baris tampilan grafik dan satuan waktu yang disiapkan pada kolom tampilan grafik.

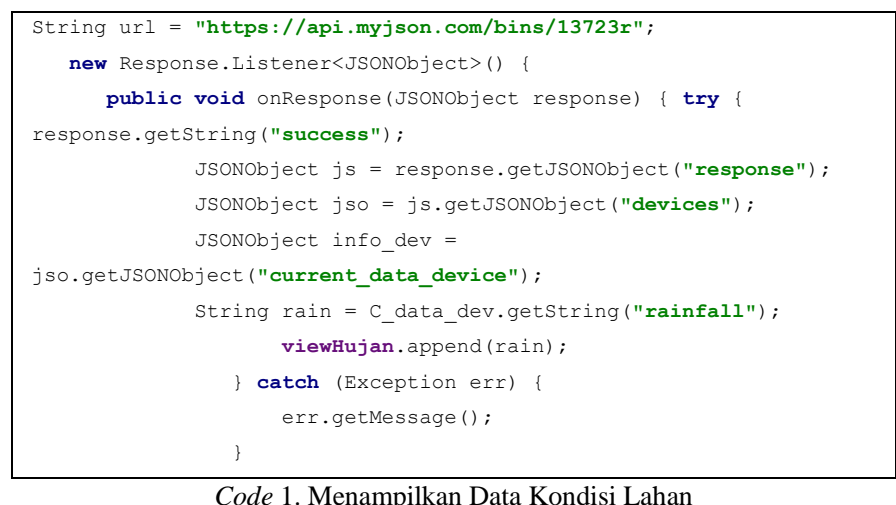

Code 1 berfungsi untuk menampilkan data kondisi yang ada dilahan. Data berupa json data diambil dari web service dengan menggunakan Final JsonObjectRequest yang di inisialisasikan sebagai request, Final digunakan karena value dari final tidak dapat digantikan dengan data lainnya. Data yang berupa Json Object diambil dengan Request.Method.GET dimana get merupakan method default dari sebuah website. Data yang didapatkan berupa JsonObject ditampung dalam inisialisasi dari response, selanjutnya untuk menhandle error ketika mengambil data digunakanlah try \& catch jika data berhasil didapatkan maka akan dilanjutkan dengan menampilkan data ke view Home Page data dari JsonObject akan ditampung dalam variable string yang kemudian disesuikan dengan target data yang akan ditampilkan, dan append digunakan untuk menampilkan data ke masing-masing id dari view Home Page.

Berdasarkan pengujian aplikasi pada Tabel I didapatkan bahwa sistem monitoring lahan tersebut memenuhi kriteria untuk dapat digunakan. 
TABEL I

PENGUJIAN APLIKASI MONITORING LAHAN

\begin{tabular}{|c|c|c|c|}
\hline No & $\begin{array}{l}\text { Data } \\
\text { Pengujian }\end{array}$ & Keterangan & $\begin{array}{l}\text { Hasil } \\
\text { Pengujian }\end{array}$ \\
\hline 1 & $\begin{array}{l}\text { Masuk ke } \\
\text { halaman } \\
\text { registrasi }\end{array}$ & $\begin{array}{l}\text { Halaman } \\
\text { registrasi } \\
\text { berhasil } \\
\text { ditampilkan. }\end{array}$ & Berhasil \\
\hline 2 & $\begin{array}{l}\text { Masuk ke } \\
\text { halaman } \\
\text { login setelah } \\
\text { registrasi } \\
\text { berhasil. }\end{array}$ & $\begin{array}{l}\text { Halaman } \\
\text { registrasi } \\
\text { berhasil } \\
\text { ditampilkan. }\end{array}$ & Berhasil \\
\hline 3 & $\begin{array}{l}\text { Masuk ke } \\
\text { tampilan } \\
\text { menu utama }\end{array}$ & $\begin{array}{l}\text { Tampilan } \\
\text { menu utama } \\
\text { berhasil } \\
\text { ditampilkan. }\end{array}$ & Berhasil \\
\hline 4 & $\begin{array}{l}\text { Menampilkan } \\
\text { grafik }\end{array}$ & $\begin{array}{l}\text { Data grafik } \\
\text { dapat } \\
\text { ditampilkan. }\end{array}$ & berhasil \\
\hline
\end{tabular}

Beta testing dilakukan untuk melakukan evaluasi terhadap sistem yang telah dibuat, pihak yang melakukan penilaian adalah para user atau responden yang tidak terlibat dalam proses perancangan sistem. Penilaian didapat dengan mengajukan beberapa pertanyaan sebagai berikut:

1. Tampilan aplikasi sudah baik atau masih butuh perbaikan.

2. Aplikasi mudah digunakan.

3. Data grafik mudah dipahami.

4. Akses data lebih cepat.

5. Apakah anda puas dengan aplikasi sistem monitoring lahan.

TABEL III

LAHAN PERSENTASE KUESIONER

\begin{tabular}{|c|c|c|c|c|c|c|c|}
\hline \multirow{2}{*}{$\begin{array}{c}\text { Pertan } \\
\text { yaan }\end{array}$} & \multicolumn{4}{|c|}{$\begin{array}{c}\text { Skala Penilaian } \\
\text { * Frekuensi } \\
\text { Kemunculan } \\
\text { Data }\end{array}$} & $\begin{array}{c}\text { Total } \\
\text { Skor }\end{array}$ & $\begin{array}{c}\text { IKK } \\
(\%)\end{array}$ \\
\cline { 2 - 7 } & $\mathbf{1}$ & $\mathbf{2}$ & $\mathbf{3}$ & $\mathbf{4}$ & $\mathbf{5}$ & & \\
\hline 1 & - & - & 3 & 16 & - & 19 & $64 \%$ \\
\hline 2 & - & - & - & 20 & - & 20 & $80 \%$ \\
\hline 3 & - & 4 & 9 & - & - & 13 & $52 \%$ \\
\hline 4 & - & - & - & 20 & - & 20 & $80 \%$ \\
\hline 5 & - & - & - & 20 & - & 20 & $80 \%$ \\
\hline
\end{tabular}

Dari Tabel II di atas, 64\% responden menyatakan tampilan aplikasi sudah baik, 80\% menyatakan aplikasi mudah digunakan, $52 \%$ responden menyatakan data grafik mudah dipahami, $80 \%$ responden menyatakan akses data lebih cepat, $80 \%$ responden menyatakan puas dengan hasil aplikasi sistem monitoring lahan dengan rata-rata 71,2\%.

\section{KESIMPULAN}

Kesimpulan yang dapat diambil berdasarkan hasil pembahasan yang dilakukan pada aplikasi Mobile Berbasis Android untuk Monitoring Lahan adalah sebuah aplikasi mobile berbasis Android dengan nama aplikasi SISMOLA (Sistem Monitoring Lahan). Informasi perkembangan kondisi lahan dan data grafik yang ditampilakan diperoleh dari database melalui web service. Alat sensor dilengkapi dengan teknologi arduino uno untuk mendapatkan data dari lokasi lahan pertanian. Data yang dihasilkan akan dikirimkan ke database melalui web service. Data yang ada pada database akan ditampilkan di aplikasi sismola dengan memanfaat API yang dibuat oleh web server sehingga data dapat ditampilkan pada aplikasi sismola berbasis mobile Android. Selanjutnya, aplikasi ini harus menggunakan internet dalam penggunaannya. RESTful web service sebagai API untuk menyimpan data dan mengubah data tersebut menjadi data JSON sehingga data dapat ditampilkan pada aplikasi.

Hasil pengujian antarmuka Android untuk menampilkan informasi kondisi lahan pertanian dan menampilkan data grafik yang diperbarui setiap 5 menit. Aplikasi yang dihasilkan dapat digunakan pemilik lahan dan para petani untuk mendapatkan informasi lahan secara realtime. Pemilik lahan dan para petani hanya perlu download dan install aplikasi lalu melakukan register dan login untuk bisa masuk ke menu utama. Selanjutnya di menu utama, pemilik lahan dan para petani bisa mendapatkan informasi dan perkembangan kondisi lahan. Saran untuk pengembangan ke depannya, aplikasi ini perlu menambahkan fitur untuk upload foto lahan agar dapat dipakai dalam melakukan analisa seperti pemantauan tanaman di lahan pertanian dan lain sebagainya.

\section{UCAPAN TERIMA KASIH}

Dalam melaksanakan riset ini, tentu ada dukungan dari banyak pihak mulai dari anggota keluarga, rekan kerja hingga para petani di lahan pertanian. Secara khusus juga riset ini terlaksana karena didukung oleh DIKTI dengan grant program No B/87/E3/RA.00/2020. Untuk itu kepada semua pihak yang terlibat kami ucapakan terima kasih.

\section{DAFTAR PUSTAKA}

[1] T. Davies, "Internet of things," J. Inst. Telecommun. Prof., vol. 9, no. 4 , pp. 38, 2015.

[2] (2019) Survey gs.statcounter. [Online]. Tersedia: https://gs.statcounter.com

[3] Pahlevi. Alvian. "Sistem Informasi Pengelolaan Lahan Kawasan Hutan Berbasis Web". Vol. 2, No. 1, pp.16-21, 2018.

[4] Yudhana, Anton, dkk. "Aplikasi Android untuk Monitoring kualitas Lahan Pertanian". Prosiding SNST ke-7 Tahun 2016 Fakultas Teknik Universitas Wahid Hasyim Semarang 7, pp. 7 12, 2018.

[5] Sintia. W, dkk. "Rancang Bangun Sistem Monitoring Kelembaban Tanah dan Suhu Udara berbasis GSM SIM900A Dan Arduino Uno". Jurnal Kumparan Fisika, vol. 1, No 2. pp. 60-65, 2018.

[6] Ibadarrohman, N. S. Salahuddin, A. Kowanda, "Sistem Kontrol dan Monitoring Hidroponik berbasis Android," Konferensi 
Nasional Sistem Informasi (KNSI), STMIK ATMA LUHUR Pangkalpinang, pp. 8-9, 2018.

[7] O. K. Sulaiman, A. Widarma, "Sistem Internet of Things (IoT) Berbasis Cloud Computing Dalam Campus Area Network". Conference: Seminar Nasional Fakultas Teknik UISU, pp.9, 2017.

[8] (2020)

$$
\text { Android. }
$$
[Online].

Tersedia: https://developer.android.com

[9] Sugiyono. Metode Penelitian Kuantitatif Kualitatif dan
R\&D. Bandung: Alfabeta.2010.

[10] Pressman, Roger, S. 2012. Rekayasa Perangkat Lunak.Pendekatan Praktisi. Edisi 7. Yogyakarta : Andi 2013.

[11] F. R. Industri, I. Iqbal, R. W. Witjaksono, and M. T. Kurniawan, "Perancangan Aplikasi Penjualan Berbasis Web Dengan Metode Prototyping Pada CV Khatulistiwa," eProceedings Eng., vol. 2, no. 1, pp. 1083-1097, 2015. 